Article

\title{
Oscillating Heat Pipe Cooling System of Electric Vehicle's Li-Ion Batteries with Direct Contact Bottom Cooling Mode
}

\author{
Ri-Guang Chi and Seok-Ho Rhi * \\ Applied Thermal Engineering Lab, School of Mechanical Engineering, Chungbuk National University, \\ 1 ChungDae-ro, SeoWon-gu, Cheongju, Chungbuk 28644, Korea; jiyirguang@naver.com \\ * Correspondence: rhi@chungbuk.ac.kr
}

Received: 30 March 2019; Accepted: 30 April 2019; Published: 5 May 2019

\begin{abstract}
Recently, the use of electrical vehicles has abruptly increased due to environmental crises. The high energy density of lithium-ion batteries is their main advantage for use in electric vehicles (EVs). However, the thermal management of Li-ion batteries is a challenge due to the poor heat resistance of Lithium ions. The performance and lifetime of lithium ion batteries are strongly affected by the internal operating temperature. Thermal characterization of battery cells is very important to ensure the consistent operation of a Li-ion battery for its application. In the present study, the OHP (Oscillating Heat Pipe) system is proposed as a battery cooling module, and experimental verification was carried out. OHP is characterized by a long evaporator section, an extremely short condenser section, and almost no adiabatic section. Experimental investigations were conducted using various parameters such as the filling ratio, orientation, coolant temperature, and heat flux. Average temperature of the heater's surface was maintained at $56.4{ }^{\circ} \mathrm{C}$ using $14 \mathrm{~W}$ with $25^{\circ} \mathrm{C}$ coolant water. The experimental results show that the present cooling technology basically meets the design goal of consistent operation.
\end{abstract}

Keywords: Oscillating Heat Pipe; Li-ion battery cooling; electric vehicles; heat transfer; battery thermal management

\section{Introduction}

Climate and environmental crisis problems that have emerged in recent years, have led to the proposition of new energy solutions, including the substitution of combustion engines by electrical systems accompanied with Li-ion batteries. The $\mathrm{CO}_{2}$ intensity of electric vehicles (EVs) can be determined by the specific mixture of power generation sources used for driving, such as coal, nuclear, or renewable power sources, as well as the carbon intensity of the vehicle manufacturing process. The high energy efficiency components of electric vehicles allow them to significantly cut $\mathrm{CO}_{2}$ emissions with respect to internal combustion engines. The IEA (International Energy Agency) (2017a) observed that, in 2015, electric cars in Europe emitted $\sim 50 \%$ less $\mathrm{CO}_{2}$ than gasoline cars and $40 \%$ less than diesel cars [1].

To increase the driving range of EVs, a large number of high energy density Lithium-ion batteries should be installed. However, Lithium-ion batteries have a shortcoming in heat resistance-a temperature that is too high or too low will result in a drastic reduction in battery capacity and service life [2,3]. Studies have shown that the heat inside Lithium-ion batteries is mainly induced from reactions that produce Ohmic heat and polarization heat [4-6]. Various models have been proposed based on these heat generation mechanisms. Among them, the most widely used model is the Bernardi model because of its simple logics and reasonable accuracy [7]. Heubner et al. [8] conducted research 
on the heat generation of a $\mathrm{LiCO}_{2} /$ graphite lithium ion battery with a $0.2-1 \mathrm{C}$ discharge rate (discharge rate $1 \mathrm{C}=$ battery capacity/one hour). Total heat generation was between 50 and $150 \mathrm{~kJ} / \mathrm{L}$. Liu [9] carried out the research on cell aging due to heat generation under conditions of 2 and $4 \mathrm{C}$. The maximum heat generation was 9 and $35 \mathrm{~W}$, respectively. Todd M. Bandhauer [10] investigated the heat generation of $\mathrm{C} / \mathrm{LiFePO}_{4}$ lithium ion batteries with different current magnitudes. He reported that heat generation reached $200 \mathrm{~W} / \mathrm{L}$ with a current of $5 \mathrm{~A}$. Heat generation from a $\mathrm{LiFePO}_{4}(20 \mathrm{Ah})$ battery was investigated by Panchal [11], who showed that the rate of heat generation was $13 \mathrm{~W}$ for a discharge rate of $1 \mathrm{C}$.

Conventional air cooling and water cooling methods have been used to solve the thermal problem of batteries. Choi [12] investigated the effect of the wind speed on air cooling using a battery size of $240 \mathrm{~mm} \times 130 \mathrm{~mm} \times 13.4 \mathrm{~mm}$, a channel size of $210 \mathrm{~mm} \times 2-6 \mathrm{~mm}$, and a coolant flow rate of 2-6 $\mathrm{m}^{3} / \mathrm{h}$. Under a wind speed of $6 \mathrm{~m}^{3} / \mathrm{h}$ and a 40 A square pulse cycle, the temperature of the battery cell was maintained at about $37.5^{\circ} \mathrm{C}$. Yu [13] conducted air convection cooling for a battery pack with a size of $620 \mathrm{~mm} \times 430 \mathrm{~mm} \times 310 \mathrm{~mm}$ and a coolant flow rate of $0.1-2 \mathrm{~m}^{3} / \mathrm{min}$. Under a $1 \mathrm{C}$ discharge rate and an air flow rate of $2 \mathrm{~m}^{3} / \mathrm{min}$, the maximum temperature of the new battery pack was reduced by nearly $4.5^{\circ} \mathrm{C}$ compared to the original pack. Ling [14] performed research work on air cooling methods for 18,650 battery cooling. The spacing between centers of two neighboring cells was $30 \mathrm{~mm}$ and the wind speed was varied between 1 and $5 \mathrm{~m} / \mathrm{s}$. Under a discharge rate of $1.5 \mathrm{C}$ and an air speed of $1 \mathrm{~m} / \mathrm{s}$, the battery's maximum temperature rose sharply to $60^{\circ} \mathrm{C}$, and under air speeds higher than $3 \mathrm{~m} / \mathrm{s}$, the temperature was kept below $45^{\circ} \mathrm{C}$. Bai [15] reported a PCM (phase change material) battery cooling method with a water flowing cold plate. The battery size used was $170 \mathrm{~mm}$ $\times 230 \mathrm{~mm} \times 12 \mathrm{~mm}$, the height of the cold plate was $2-7 \mathrm{~mm}$, and the mass flow rate was $0.25-3 \mathrm{~g} / \mathrm{s}$. After five continuous charge-discharge cycles at 0.5 and $2 \mathrm{C}$, the maximum temperature was kept below $42{ }^{\circ} \mathrm{C}$. However, due to the small flow passage, a 42 Pa pressure drop was observed at a channel width of $3 \mathrm{~mm}$. Tong [16] investigated various parameters of a cooling system with a water coolant plate, such as the flow rate, section size, and discharge rate. Under a coolant velocity of $0.1 \mathrm{~m} / \mathrm{s}$ and a discharge rate of $1 \mathrm{C}$, the average temperature difference was only $2{ }^{\circ} \mathrm{C}$. Huo [17] investigated a mini channel cold plate cooling system with six $1 \mathrm{~mm}$ thick micro channels. At a flow rate of $1 \mathrm{~kg} / \mathrm{s}$, the maximum temperature was maintained between 30 and $32{ }^{\circ} \mathrm{C}$. However, the pressure loss reached $478 \mathrm{~Pa}$. To make the data compatible for EV/HEV (hybrid electric vehicle) application, Panchal [18] developed a modified exponential-polynomial equivalent circuit model to simulate the temperature and voltage fields with water cooling. Under a discharge rate of $1-2 \mathrm{C}$ and working temperatures of 5 , 15,25 , and $35^{\circ} \mathrm{C}$, the model showed good agreement with the experimental results.

However, due to the low thermal conductivity of air and the large volume of the air cooling system, the cooling system requires a large heat transfer surface area and flow passage for air convection cooling. Furthermore, due to the high viscosity of water, the water cooling system requires extra energy to circulate liquid.

The importance of the heat pipe as a thermal superconductor for thermal management is gradually being realized. Liu [19] carried out research on battery cooling with an ultra-thin micro heat pipe $(168 \mathrm{~mm} \times 10 \mathrm{~mm} \times 1 \mathrm{~mm})$. In their system, one end of the heat pipe is inserted between the batteries, and the other end is a finned sink. When air cooling was conducted at a discharge rate of $3 \mathrm{C}$, the maximum temperature of the battery was $53^{\circ} \mathrm{C}$. Wang [20] investigated the battery cooling method with an L-shaped heat pipe. The heat pipe evaporation section was flattened $(120 \mathrm{~mm} \times 13.16 \mathrm{~mm}$ $\times 4.5 \mathrm{~mm}$ ), and the lower condensation section was cylindrical (length $=50 \mathrm{~mm}$ and diameter $=$ $10 \mathrm{~mm}$ ). Under a heating rate of $20 \mathrm{~W} /$ cell, the maximum temperature of the battery was about $50^{\circ} \mathrm{C}$. Hong [21] investigated the loop heat pipe battery cooling system with system inclination and battery heat generation. The evaporation section of a loop heat pipe is a flat plate with 25 micro-channels (width $=3 \mathrm{~mm}$ and depth $=0.6 \mathrm{~mm}$ ) inside it. The inner and outer diameters of the loop pipe were 2.4 and $3 \mathrm{~mm}$, respectively. 
Due to the importance of thermal management in high heat generation Li-ion batteries, heat pipes are adopted in many cooling system as an efficient heat transfer device, but most heat pipe-adapted cooling systems are bottom heating-top or side cooling systems. These types of cooling system have good cooling performance but take up a lot of space. In addition, their structures are not convenient in terms of battery maintenance.

OHP, a highly efficient and simple-structured type of heat pipe, is now being studied extensively. As shown in Figure 1, it consists of a curved channel and working fluid, which can be described as the evaporator, adiabatic, and condenser sections. Because the vapor bubble is separated by multiple liquid slugs, when the heat is supplied to the evaporator section, a pressure difference is created between the bubbles, causing the liquid plug to oscillate between the evaporator section and the condenser section, thereby transferring heat.



Figure 1. Oscillating heat pipe as a bottom cooling mode.

Rao [22] studied the OHP (four turns, inner diameter $=1.8 \mathrm{~mm}$, and outer diameter $=3 \mathrm{~mm}$ ) for battery cooling. Under $20 \mathrm{~W}$ of heating, at $800 \mathrm{~s}$, steady state was reached, and the maximum temperature was about $55{ }^{\circ} \mathrm{C}$. In another paper, Rao reported on a cooling system that combined OHP and PCM (phase change material) [23]. Although its cooling performance was shown to be good, it is still bottom heating/top cooling. Qu [24] used a special OHP for the battery thermal management of hybrid-electric vehicles. The condensation section and evaporation section of OHP were a micro-grooved copper tube system. At $121 \mathrm{~W}$, the micro-grooved cooling system could maintain a temperature of $50{ }^{\circ} \mathrm{C}$.

Chi [25] proposed a top heating/bottom cooling OHP model shown in Figure 1. As shown in Figure $2 \mathrm{a}$, their OHP cooling system has the conventional rounded lower end with a short $(15 \mathrm{~mm})$ condenser section. However, as the number of OHP increases, the structure of cooling of system will also become more complicated.

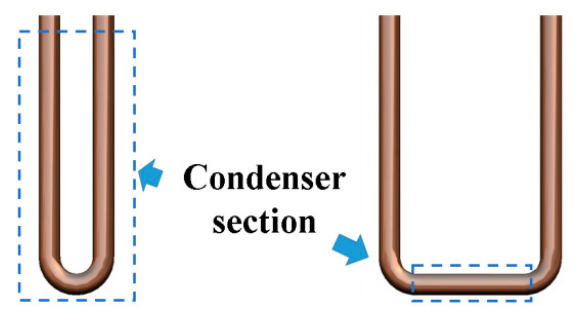

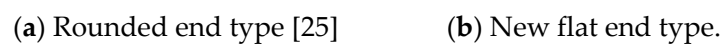

Figure 2. Configuration of the OHP condenser section.

According to the cooling method used to transfer heat from the battery to the outside environment, cooling technology can carry out various liquid cooling methods (air, water, oil-based fluids, and refrigerants, etc.) and PCM. In addition, heat pipe cooling technology is also under development $[7,26]$. 
Table 1 shows the comparison of various cooling methods. As described in Table 1, liquid cooling methods are mainly divided into direct and indirect method. The direct cooling type involves direct immersion of the battery into the high-resistance coolant, so the cooling efficiency is very high. However, there are several problems, such as electrical short-circuiting, electrochemical corrosion, and sealing. Furthermore, the battery is immersed in the coolant, so maintenance and replacement will be very troublesome. Indirect type involves letting water flow through the channel between the batteries. Compared with the direct type, some problems are alleviated, but since the channels are generally small and the pressure drop is also very large, the pump consumes a lot of electric energy, thereby reducing the electric vehicle travel $[7,27,28]$. Due to the low specific heat and low thermal conductivity, the efficiency of air cooling is very low. However, the structure is simple and there is no disadvantage of water cooling, so the method of increasing the flow rate or the cross-section of the passage is used in the battery cooling of the electric vehicle $[7,27,28]$. PCM cooling uses the principle of heat absorption during phase change. Although PCM can absorb a large amount of heat, its thermal conductivity is low, for example, paraffin has a thermal conductivity of only $0.149-0.514 \mathrm{~W} / \mathrm{m} \cdot \mathrm{K}$. The temperature will increase dramatically after PCM melts; therefore, PCM is used in combination with air cooling or liquid cooling. Moreover, the PCM density is large, and if used in a large amount, the battery space is reduced $[26,27,29,30]$.

As a heat superconductor, the heat pipe is capable of rapid heat transfer. In most studies, the cooling section is in the upper part of the battery. This structure affects battery maintenance and updates. As a special heat pipe, OHP can work without gravity. Moreover, it is small in size and diverse in shape, so it can be applied to a large number of diverse batteries. The OHP proposed in this paper has a heating section that is much larger than the cooling section ( 20 times), so the cooling effect is not ideal. However, with the adjustment of parameters, we believe that the performance of $\mathrm{OHP}$ will get better and better.

Table 1. Comparison of various cooling methods [7,11-30].

\begin{tabular}{|c|c|c|c|c|c|c|}
\hline & \multicolumn{2}{|c|}{ Liquid Cooling $[7,15-18,27,28]$} & \multirow{2}{*}{$\begin{array}{c}\text { Air Cooling } \\
{[7,12-14,27,28]}\end{array}$} & \multirow{2}{*}{$\begin{array}{l}\text { PCM }[15,23, \\
26,27,29,30]\end{array}$} & \multirow{2}{*}{$\begin{array}{l}\text { Heat Pipe } \\
{[19-21]}\end{array}$} & \multirow{2}{*}{ OHP [2-25] } \\
\hline & Direct (Immersion) & Indirect & & & & \\
\hline Cooling efficiency & $\mathrm{A}$ & $\mathrm{A}$ & B & B & $\mathrm{A}$ & B \\
\hline System complexity & $\mathrm{C}$ & $\mathrm{C}$ & $\mathrm{A}$ & $\mathrm{C}$ & $\mathrm{B}$ & $\mathrm{B}$ \\
\hline System volume & $\mathrm{A}$ & $\mathrm{A}$ & $\mathrm{C}$ & $\mathrm{B}$ & $\mathrm{C}$ & $\mathrm{A}$ \\
\hline Energy loss & $\mathrm{C}$ & $\mathrm{C}$ & A & $\mathrm{A}$ & A & A \\
\hline Maintenance & $\mathrm{C}$ & $\mathrm{C}$ & $\mathrm{A}$ & $\mathrm{A}$ & $\mathrm{B}$ & $\mathrm{A}$ \\
\hline Short circuit & $\mathrm{C}$ & $\mathrm{C}$ & A & A & $\mathrm{C}$ & A \\
\hline Lifespan & $\mathrm{C}$ & $\mathrm{C}$ & $\mathrm{A}$ & $\mathrm{A}$ & $\mathrm{A}$ & $\mathrm{A}$ \\
\hline Cost & $\mathrm{C}$ & $\mathrm{C}$ & $\mathrm{A}$ & A & $\mathrm{B}$ & B \\
\hline
\end{tabular}

* A, B, and C mean good, fair, and poor, respectively, in terms of their advantage in a battery cooling system.

The present study investigated an OHP (Oscillating Heat Pipe) battery cooling system with a condenser directly contacting the cold plate surface in bottom cooling mode, as shown in Figure 2. The performance and various effects of the system's operating parameters, such as the charging rate, orientation, pipe size, and supplied heating rate, were assessed.

\section{Experiments}

Figure 3a-e shows a battery cooling system with the new type of OHP, which will be applied to an electric vehicle. Figure 3b,e shows the present experimental setup accompanied by the OHP. The experimental setup mainly consists of an OHP, a heater, a DC-power supply (DP30-10DU, TOYOTECH, Incheon, Korea), a water flowing cooling plate $(0.01 \mathrm{~kg} / \mathrm{s})$, and a multichannel data acquisition system (Yokogawa, MX-100). The maximum critical inner diameter of the OHP can be obtained by Equations (1) and (2). Furthermore, the cooling plate has two passing flow channels, as shown in Figure 3c, and is made of aluminum alloy and sealed with a silicone ring. The bottom end outer surface of the condenser section in the OHP directly contacts the top surface of the cooling plate system. In order to reduce the thermal resistance between the cooling plate and the condenser section of the OHP, the condenser end 
and the cooling plate were bolt jointed tightly between fixed holding plate- 1 and fixed holding plate-2, as shown in Figure 3d.

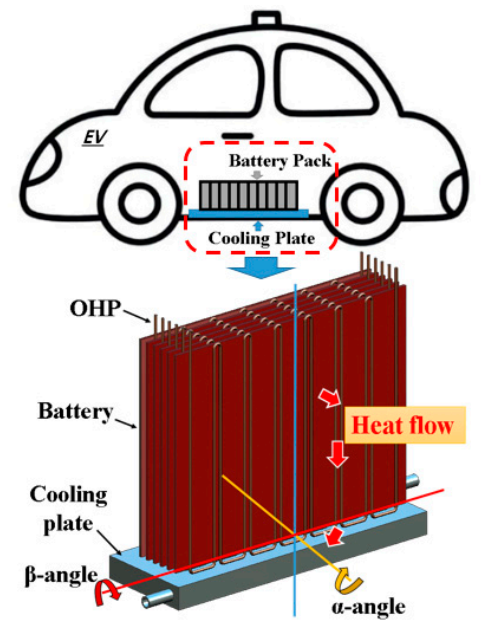

(a) Electric car cooling model using OHP

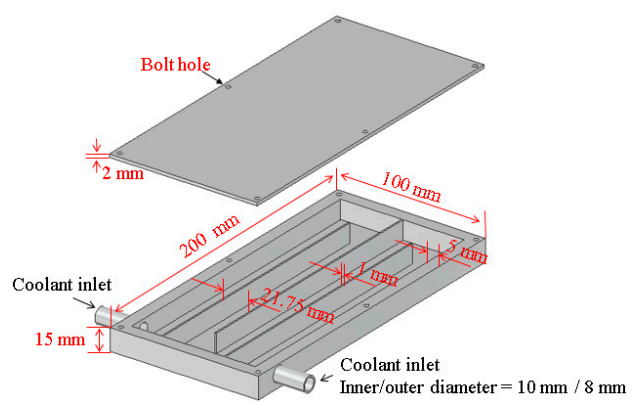

(c) Cooling plate



(b) Experimental oscillating heat pipe module

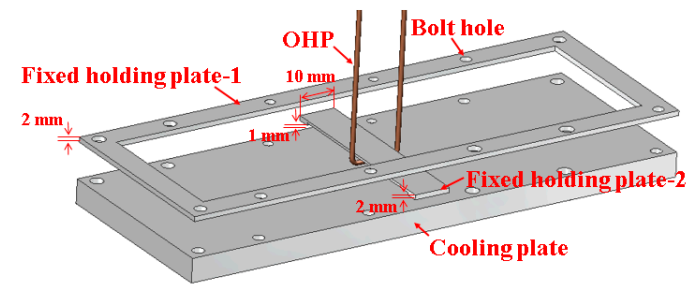

(d) Schematic diagram of the OHP condenser

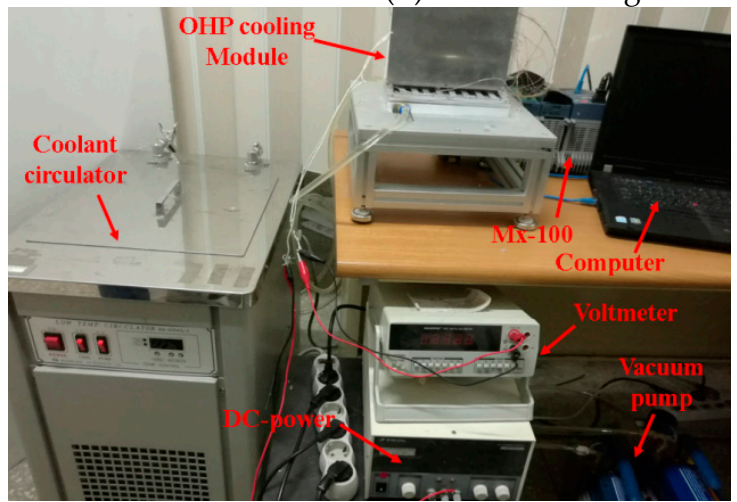

(e) Experimental Setup

Figure 3. Specific configurations of experimental system.

Despite the simple structure of the OHP, the physical flow behavior inside it is very complex, and its performance is affected by many different parameters, including the thermo physical properties of the working fluid. The OHP channel diameter for randomly separating the pulsating liquid slug/vapor plug flow of the OHP must have a Bond number $\leq 4$, as determined by Equation (1) [31]. If the Bond number is greater than 4 , the surface tension will not withstand the buoyancy driven force, and the vapor plug will not be able to collapse, so it will maintain a stable shape.

$$
B o=\frac{g\left(\rho_{l}-\rho_{v}\right) D_{i}^{2}}{\sigma}
$$


In light of this, $D_{c r}$ can be defined as Equation (2):

$$
D_{c r}=2 \sqrt{\frac{\sigma}{g\left(\rho_{l}-\rho_{v}\right)}} .
$$

Using Equation (2), when the working fluid is methanol, the critical inner diameter $D_{c r}$ of OHP is $\sim 3.2 \mathrm{~mm}$. Based on this critical inner diameter of OHP, a few commercial copper tube combinations were tested. The test OHPs were fabricated using copper capillary tubes $\left(D_{o} / D_{i}=1.8 \mathrm{~mm} / 0.8 \mathrm{~mm}\right.$, $D_{o} / D_{i}=2 \mathrm{~mm} / 1 \mathrm{~mm}, D_{o} / D_{i}=2.4 \mathrm{~mm} / 1.4 \mathrm{~mm}$ ), and the end side of the evaporator was bent to $180^{\circ}$ with a $5 \mathrm{~mm}$ curvature diameter. The bottom side of the condenser was a straight pipe of $10 \mathrm{~mm}$ length, bent at $90^{\circ}$ with a $5 \mathrm{~mm}$ curvature diameter. The OHP had eight turns, as shown in Figure $3 \mathrm{~b}$. The resistance flat heater $(190 \mathrm{~mm} \times 150 \mathrm{~mm})$ was used to simulate the Li-ion battery, which is modeled as an LG chem Li-ion car battery. Heat generation rates of 10, 14, and 20 Watts were used based on information from the literature $[7,11]$.

In the present experimental system, K-type thermocouples (TT-K-36-SLE, Omega, Stamford, CT, USA) and a data acquisition module (MX-100, Yokogawa, Tokyo, Japan) were used to measure temperatures in many positions. The temperature measurement points of the thermocouples are shown in Figure 4 in the following positions: numbers 1-5 in the heater surface, numbers $6-8$ in the upper part of the evaporation section of the OHP, numbers 9-11 in the middle part of the evaporation section of the OHP, numbers 12-14 in the bottom part of the evaporation section of the OHP, numbers 15-17 in the condenser section of the OHP, and numbers 18 and 19 in the coolant outlet and inlet.



(a) Thermocouple positions on the heater surface

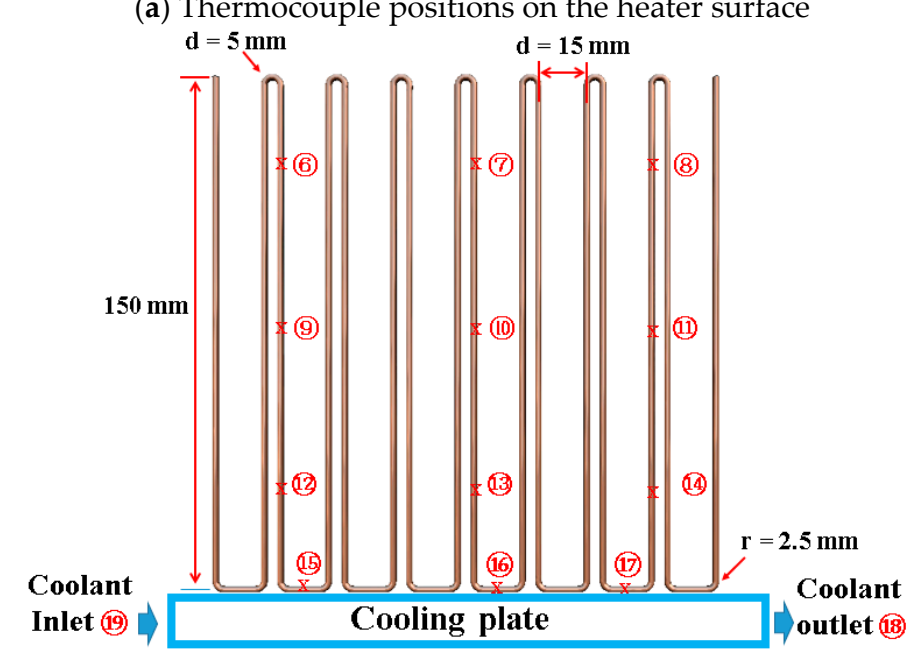

(b) Thermocouple positions on the OHP surface

Figure 4. Thermocouple positions.

To estimate the thermal performance of the OHP and the system, the thermal resistances of the $\mathrm{OHP}$ and the system were estimated by Equations (3)-(5). The OHP operation based on the charging rate was evaluated with $\mathrm{R}_{\mathrm{OHP}}$, where $\overline{T_{\text {evap }}}, \overline{T_{\text {cond }}}$, and $\overline{T_{\text {heater }}}$ are the average temperatures of the nine evaporator positions, three condenser positions, and five heater positions, respectively, and $T_{\text {Cool }}$ is the 
coolant inlet point. Input heat was supplied to the evaporator using a DC power transformer through a flat thermal pad. The input power was calculated by Equation (6), where $V$ and $I$ are the input voltage and electric current, respectively [32].

$$
\begin{gathered}
\Delta \mathrm{T}=\overline{T_{\text {evap }}}-\overline{T_{\text {cond }}} \\
\mathrm{R}_{O H P}=\frac{(\Delta \mathrm{T})}{Q} \\
\mathrm{R}_{S Y S}=\frac{\left(\overline{T_{\text {heater }}}-T_{\text {cool }}\right)}{Q} \\
Q=V I
\end{gathered}
$$

In the present work, the parameters influencing the thermal resistance were the temperature $(\mathrm{T})$, current (I), and voltage (V). The voltage and current error of the DC power supply was $\pm(0.1 \% \mathrm{rdg}+5$ digits), and the temperature error of $\mathrm{MX}-100$ was $\pm\left(0.05 \% \mathrm{rdg}+0.7^{\circ} \mathrm{C}\right) . c_{i}$ and $\sigma_{i}$ are the sensitivity coefficient and the error of each parameter, respectively, and they were calculated by Equation (7) [33]:

$$
c_{i}=\frac{\partial R_{O H P}}{\partial x_{i}}
$$

Finally, the standard uncertainty error of $R_{O H P}$, which was calculated by Equation (8), under heating at $10 \mathrm{~W}$ was $\pm 0.12^{\circ} \mathrm{C} / \mathrm{W}$.

$$
\Delta \mathrm{R}=\sum_{1}^{i}\left(\left|c_{i} \sigma_{i}\right|\right)
$$

To analyze the oscillation behavior of the temperature at a specific location on the OHP, the Fast Fourier Transform (FFT) method was applied for temperature position no. 16, which is an interface temperature position between the evaporator and the condenser. The FFT Power Spectrum Density (PSD) was calculated by Equation (9), where $r_{x x}$ is the auto-correlation function of the input signal. The PSD and frequency were computed by Equations (10) and (11), where $N_{s p}$ and $\Delta t$ are the number of input data points and the sampling interval, respectively [34]:

$$
\begin{gathered}
p_{x x}=\sum_{m=-\infty}^{\infty} r_{x x}(m) e^{-j \omega m} \\
\operatorname{PSD}_{n}=\frac{\mathrm{a}^{2}+b^{2}}{N_{s p}} \\
f_{n}=\frac{n}{N_{s p} \Delta t}
\end{gathered}
$$

\section{Results and Discussion}

Figure 5a,b shows two types of OHP working conditions with different amounts of charge. Under constant heating $(\mathrm{Q}=20 \mathrm{~W})$ and a certain range of charge (volume fraction $(\mathrm{VF})=14.7 \%$ ), the OHP system temperature shows stable oscillatory behavior. However, if this range is exceeded, the working status will change from stable to intermittently unstable behavior. As shown in Figure 5a, the temperature oscillation of the evaporation section is constantly maintained in the range of $50-60{ }^{\circ} \mathrm{C}$. However, when VF increased to $24.5 \%$ with the same heat flux, the temperature of the evaporation section largely fluctuated from 60 to $70{ }^{\circ} \mathrm{C}$. When the $\mathrm{Q}$ was $10 \mathrm{~W}$ and the VF increased from $4.9 \%$ to $9.8 \%$, the thermal resistance of $\mathrm{OHP}$ decreased from 1.5 to $1.43 \mathrm{~K} / \mathrm{W}$. However, when the VF increased to $14.7 \%$, the thermal resistance of $\mathrm{OHP}$ increased to $1.66 \mathrm{~K} / \mathrm{W}$ due to intermittent temperature fluctuations. When $Q$ was $14 \mathrm{~W}$, the minimum value of the thermal resistance $(1.29 \mathrm{~K} / \mathrm{W})$ was observed at a VF of 
$14.7 \%$. When $\mathrm{Q}$ increased to $20 \mathrm{~W}$, the optimal value of $\mathrm{VF}$ was still $14.7 \%$ and the thermal resistance of OHP was $1.11 \mathrm{~K} / \mathrm{W}$. Generally, as VF increased, the thermal resistance of OHP decreased firstly, and then increased with increasing VF, as shown in Figure $5 c$. This is because if the charged amount of working fluid is insufficient, the working fluid cannot be sufficiently supplied to the evaporator section of OHP, resulting in a dry-out and increased OHP thermal resistance. If $\mathrm{Q}$ also increases, the dry-out phenomena in the evaporator becomes more serious and the thermal resistance of OHP increases, as shown in the Figure $5 \mathrm{c}$ with $\mathrm{VF}=4.9 \%$. With the increase of $\mathrm{VF}$, dry-out is well activated in the evaporation section of $\mathrm{OHP}$ and thermal resistance of $\mathrm{OHP}$ also reduces. However, when the amount of working fluid is not excessive, the pressure drop will increase between the liquid and pipe wall, the motion of working fluid will be resisted, intermittent fluctuated operation occurs, and then subsequently, the thermal resistance will increase. When VF is sufficiently large with an increasing $Q$, the temperature difference will also increase between the evaporator and condensation sections. This will lead to an increased pressure difference between working fluids in both sections. Heat transfer is stable and thermal resistance is reduced at a VF of $9.8-14.7 \%$, as shown in Figure $5 \mathrm{c}$. This means that the optimum charging rate of an OHP system should be correctly determined. Figure $5 \mathrm{~d}$ shows a certain optimum and maximum criteria range for the charging rate, which is observed as a working condition.



(a) Stable fluctuation work

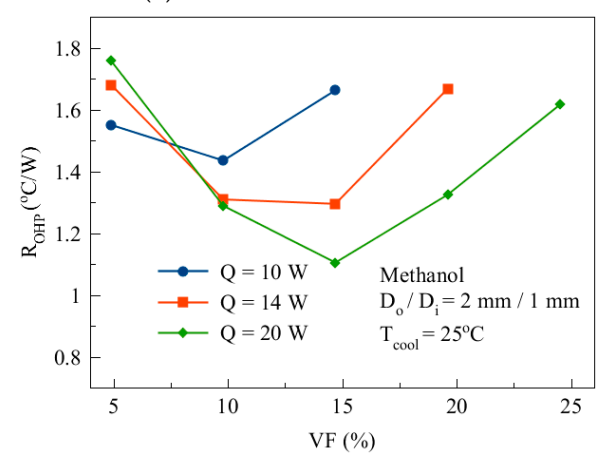

(c) Effect of VF on thermal resistance

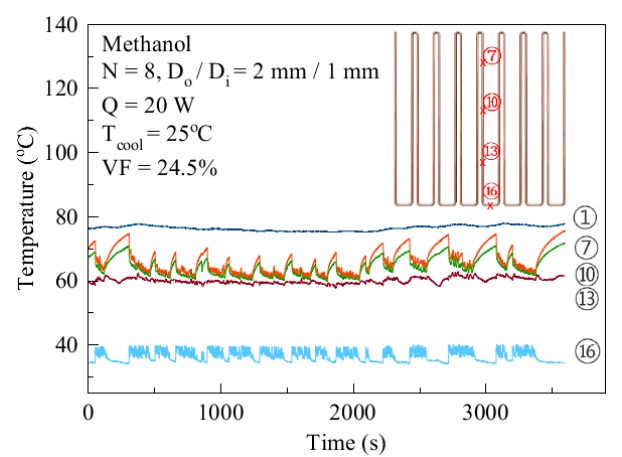

(b) Unstable fluctuation work

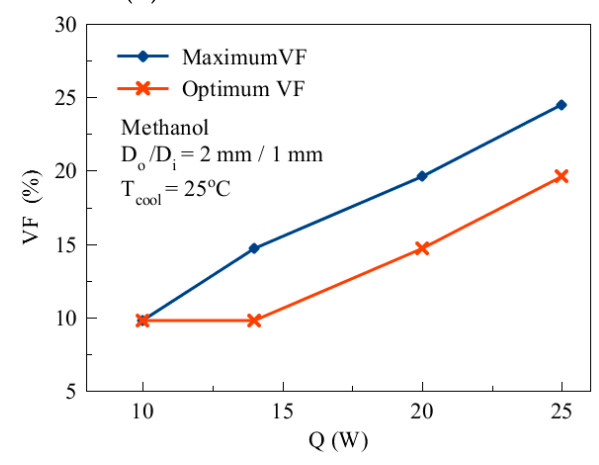

(d) Possible range of charging rate on $Q$

Figure 5. Effect of different charged volume fractions (VF).

The contact thermal resistance between the tube and the heater or cooling plate is affected by the diameter of the tube. Figure 6 shows the thermal resistance of the cooling system between the heater surface and the cooling plate under a constant heating rate in the OHP with different tube diameters and with different amounts of charge. When the $D_{o} / D_{i}$ was $1.8 \mathrm{~mm} / 0.8 \mathrm{~mm}$, the optimal VF was about $15 \%$. When the $D_{o} / D_{i}$ was $2 \mathrm{~mm} / 1 \mathrm{~mm}$, the optimal VF was $10-15 \%$. However, when the $\mathrm{D}_{\mathrm{o}} / \mathrm{D}_{\mathrm{i}}$ was $2.4 \mathrm{~mm} / 1.4 \mathrm{~mm}$, the optimal VF was about $2-10 \%$. From this, we know that the smaller the pipe diameter is, the bigger the optimal VF and the maximum VF are. This is because the larger the diameter, the larger the volume of OHP; pressure changes in the working fluid are also slow. However, in contrast, the smaller the diameter, the larger the pressure drop. Figure $6 \mathrm{~d}$ also shows the effect of $Q$ on thermal resistance with different VFs. The figure shows that the best working performance in terms 
of the thermal resistance was obtained when VF was $9.8 \%$. When VF was $9.8 \%$, the plot line trend of thermal resistance with $Q$ was not steeper than a VF of $14.7 \%$. This means that the optimum charging rate is a VF of $9.8 \%$.



(a) Effect of pipe VF on Rsys with pipe diameters $(\mathrm{Q}=10 \mathrm{~W})$

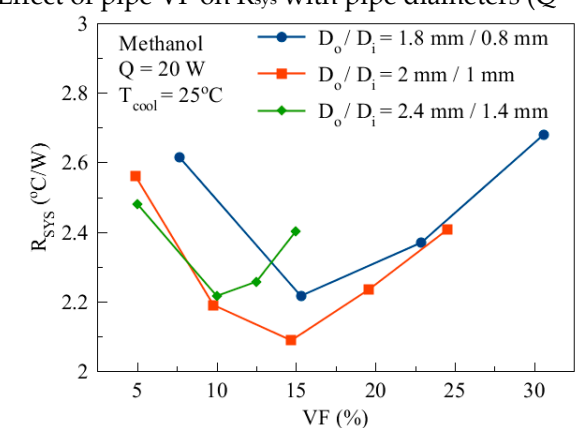

(c) Effect of VF on Rsys with pipe diameters $(Q=20 \mathrm{~W})$

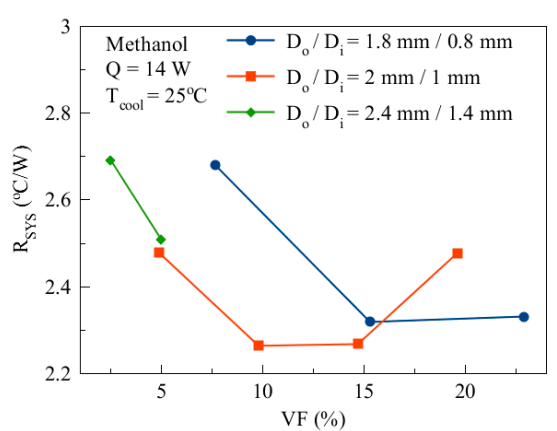

(b) Effect of pipe VF on Rsys with pipe diameters $(\mathrm{Q}=14 \mathrm{~W})$

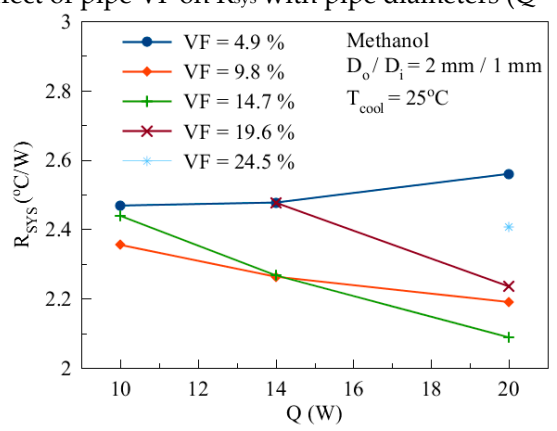

(d) Effect of $Q$ on Rsys with different VFs

Figure 6. Effect of $\mathrm{OHP}$ pipe diameters on $\mathrm{R}_{\text {sys }}$ with different $\mathrm{Q}$ and VF.

Figure 7 shows the PSD of temperature position no. 13 with a $D_{o} / D_{i}$ of $2 \mathrm{~mm} / 1 \mathrm{~mm}$ and a VF of $9.8 \%$ with different heat fluxes. As shown in Figure $7 \mathrm{a}-\mathrm{d}$, when $\mathrm{Q}$ was $10 \mathrm{~W}$, a larger PSD was distributed in the low frequency region $(0-0.75 \mathrm{~Hz})$. In the high frequency region, the PSD was small with a value of less than 1 . When $\mathrm{Q}$ increased to $14 \mathrm{~W}$ between 0.075 and $0.125 \mathrm{~Hz}$, PSD obviously increased. Compared with Q values of 10 and $14 \mathrm{~W}$, PSD obviously increased across the full frequency range when $\mathrm{Q}$ was $20 \mathrm{~W}$.

As shown in Figure 8a-d, with a $\mathrm{T}_{\text {cool }}$ of $20^{\circ} \mathrm{C}$, the peak appeared near to $0.75 \mathrm{~Hz}$ and was relatively wide. When the $\mathrm{T}_{\text {cool }}$ rose to $25^{\circ} \mathrm{C}$ (Figure $8 \mathrm{c}$ ), the peak was significantly narrower. When the $\mathrm{T}_{\text {cool }}$ continued to rise to $30^{\circ} \mathrm{C}$, not only did the peak disappear completely, PSD also decreased in the full frequency region. From this behavior, it can be understood that when the heating temperature increases or the coolant temperature decreases, the temperature difference will increase between the evaporation section and the condensation section. Thus, the pressure gradient also increases, the working fluid movement will be smooth, and larger PSD values will be distributed in the high frequency region.

Figure 9 shows the experimental result with an orientation change of $D_{o} / D_{i}=2 \mathrm{~mm} / 1 \mathrm{~mm}$ under the experimental conditions of a VF of $9.8 \%$, a Q of $14 \mathrm{~W}$, and a $\mathrm{T}_{\text {cool }}$ of $25^{\circ} \mathrm{C}$. When the $\alpha$-angle was $0^{\circ}$, the peak frequency appeared between 0.075 and $0.1 \mathrm{~Hz}$. When the $\alpha$-angle increased to $5^{\circ}$, the peak moved to the low frequency region. After the $\alpha$-angle had increased to $10^{\circ}$, the peak almost disappeared, and in the low frequency region, the PSD increased significantly. Similarly, when $\beta$ increased, the peak value of PSD between 0.05 and $0.1 \mathrm{~Hz}$ gradually reduced, and due to the increase in intermittent oscillation, the PSD in the low frequency region increased. We know from this that as the $\alpha$-angle (or $\beta$-angle) increases, intermittent oscillations occur, and larger values of PSD migrate from the high frequency region to the low frequency region and the thermal resistance increases. This is because the increase of the $\alpha$-angle causes the gravity component $g \sin (\alpha)$ to also decrease. However, 
because the $\alpha$-angle can increase the uneven distribution of the head, it has a better performance than the $\beta$-angle.

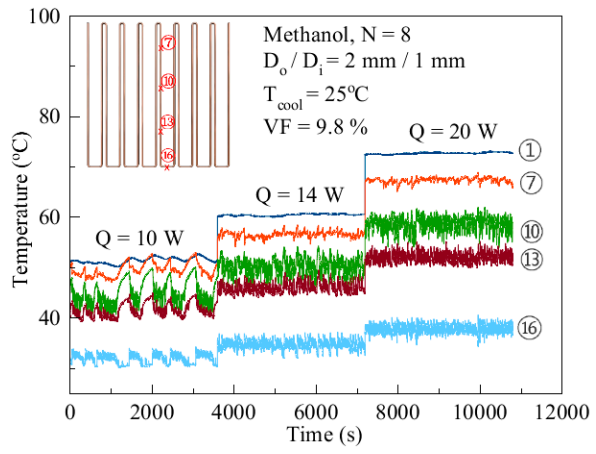

(a) Transient temperature variation with Different $Q$



(c) PSD variation, $\mathrm{Q}=14 \mathrm{~W}$

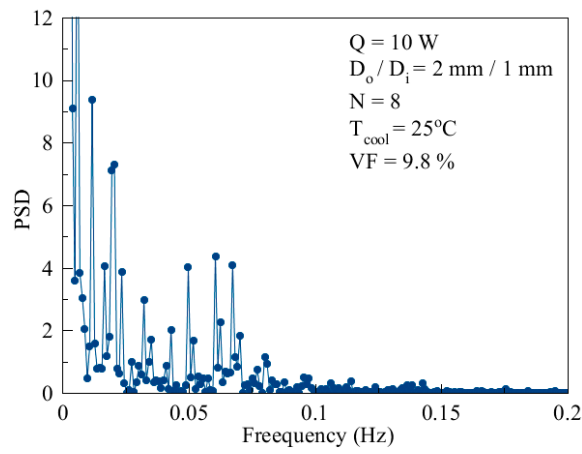

(b) Power Spectrum Density (PSD) variation, $Q=10 \mathrm{~W}$

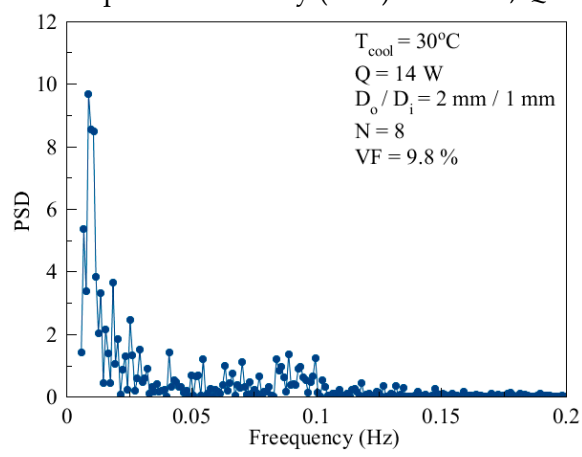

(d) PSD variation, $\mathrm{Q}=20 \mathrm{~W}$

Figure 7. Seven PSD variation with different supplied heating rates.

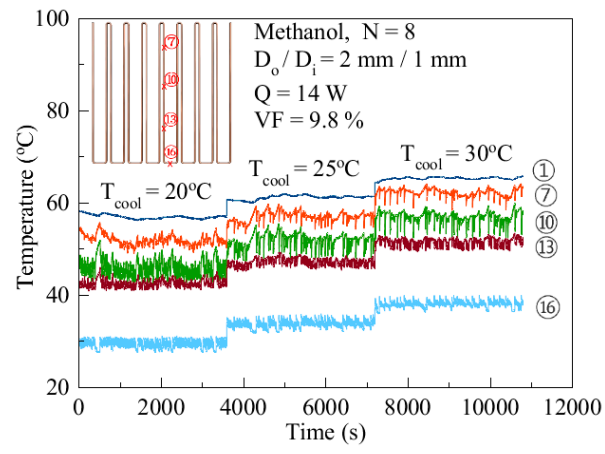

(a) Transient temperature variation with different $\mathrm{T}_{\text {cool }}$

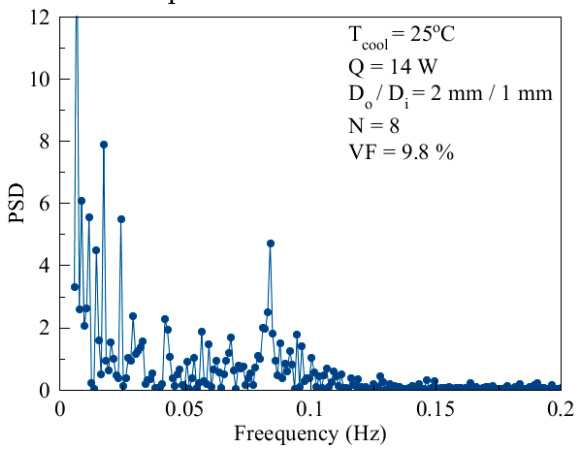

(c) PSD variation, $\mathrm{T}_{\text {cool }}=25^{\circ} \mathrm{C}$

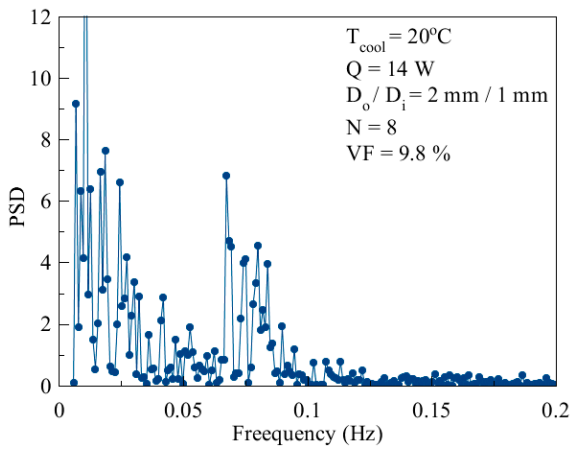

(b) PSD variation, $\mathrm{T}_{\mathrm{cool}}=20^{\circ} \mathrm{C}$



(d) PSD variation, $\mathrm{T}_{\text {cool }}=30^{\circ} \mathrm{C}$

Figure 8. PSD variation with different coolant temperatures. 


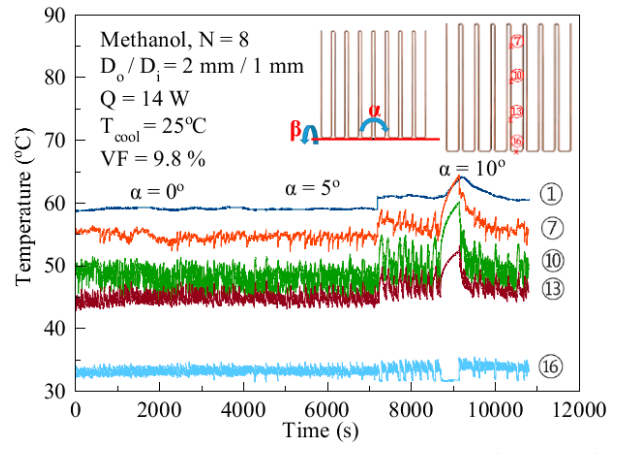

(a) Transient temperature variation with $\alpha$-angle

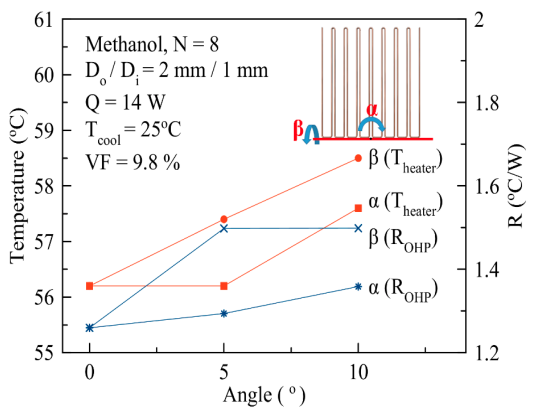

(c) Theater with different angles of inclination

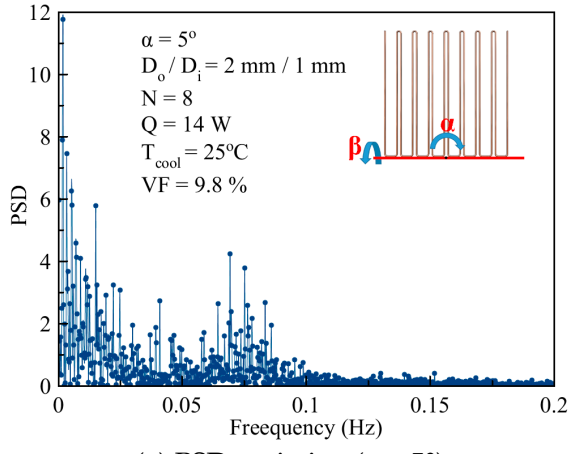

(e) PSD variation $\left(\alpha=5^{\circ}\right)$

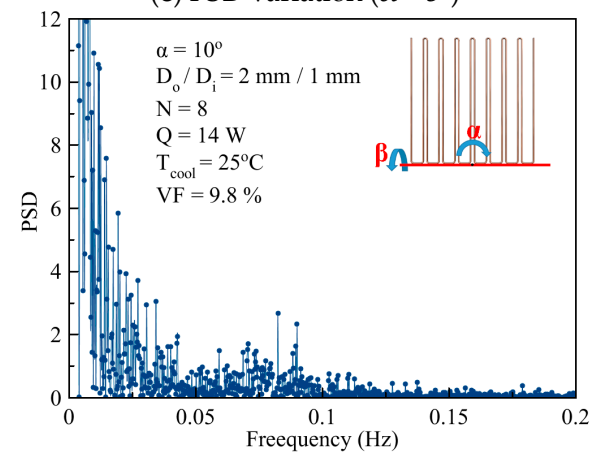

(g) PSD variation $\left(\alpha=10^{\circ}\right)$

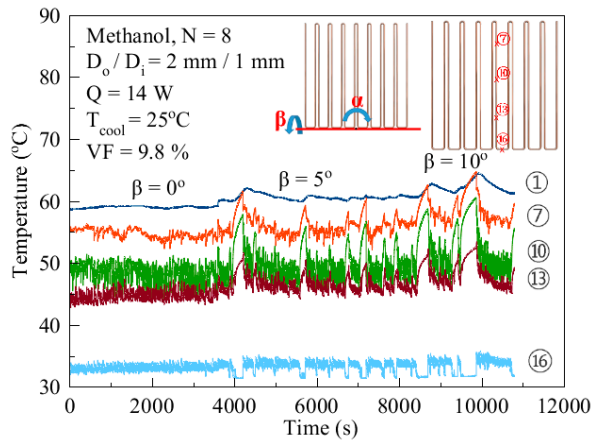

(b) Transient temperature variation with $\beta$-angle



(d) PSD variation, $\left(\alpha=0^{\circ}, \beta=0^{\circ}\right)$

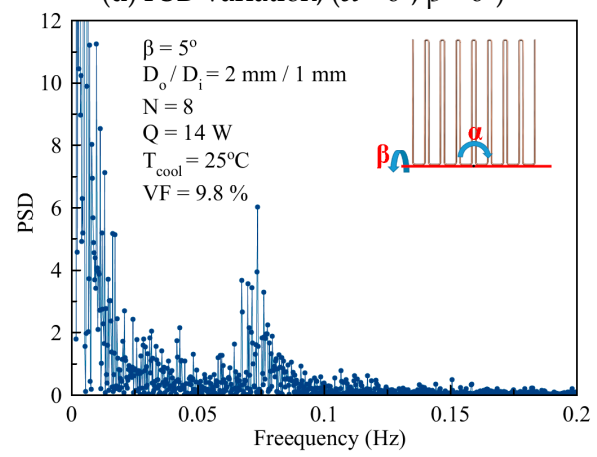

(f) PSD variation $\left(\beta=5^{\circ}\right)$

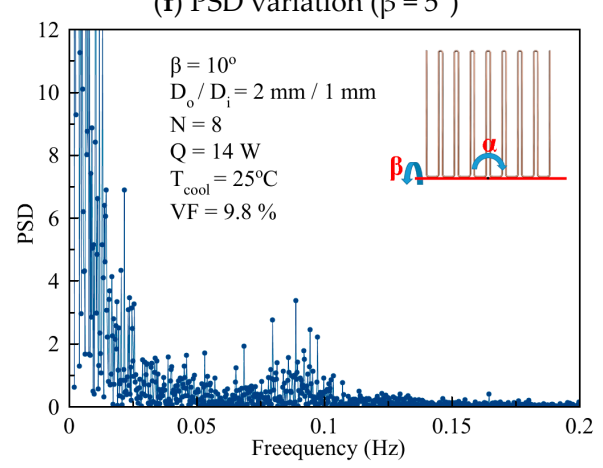

(h) PSD variation $\left(\beta=10^{\circ}\right)$

Figure 9. PSD variation with different inclination angles $(Q=14 W, \alpha$ - and $\beta$-angle).

\section{Conclusions}

In the present study, an OHP cooling system design for a Li-ion battery with a long evaporator section, a short condensing section, and eight turns, was proposed. The conclusions of experiments on various parameters and a PSD analysis are as follows:

- The heat transfer performance of the OHP system was found to be mainly dependent on the filling rate of the working fluid, that is, the greater the heating rate, the greater the optimal VF. 
- Under the same heating and cooling conditions, the thermal performance and stability of the OHP system was optimal a $D_{o} / D_{i}$ of $2 \mathrm{~mm} / 1 \mathrm{~mm}$.

- $\quad$ The OHP could be operated normally when the $\alpha$-angle (or $\beta$ ) was in the range $1-5^{\circ}$. As the angle increased, the operation became unstable with large intermittent fluctuations.

- The average temperature of the heater was maintained at around $55^{\circ} \mathrm{C}$ as a design goal with the following parameters: $\mathrm{D}_{\mathrm{o}} / \mathrm{D}_{\mathrm{i}}=2 \mathrm{~mm} / 1 \mathrm{~mm}, \mathrm{Q}=14 \mathrm{~W}, \mathrm{~T}_{\text {cool }}=25^{\circ} \mathrm{C}$, and $\mathrm{VF}=9.8 \%$. This meets the basic requirements for battery cooling.

Author Contributions: R.-G.C. conducted the experiments and analysis; S.-H.R. supervised and analyzed the research results; this research was managed and supported by S.-H.R.

Funding: This research was funded by Basic Science Research Program through the National Research Foundation of Korea (NRF), Ministry of Education (Grant No. NRF-2016R1D1A1B03930495).

Acknowledgments: This research was supported by Basic Science Research Program through the National Research Foundation of Korea (NRF) funded by the Ministry of Education (No. NRF-2016R1D1A1B03930495).

Conflicts of Interest: The authors declare no conflict of interest.

\section{Abbreviations}

Bo

DC

OHP

PSD

PCM

$\mathrm{VF}$

Nomenclature

A

B

$c_{i}$

$\mathrm{D}_{\mathrm{cr}}$

$D_{\mathrm{i}}$

$\mathrm{D}_{\mathrm{o}}$

g

I

$\mathrm{n}$

$\mathrm{N}$

$\mathrm{N}_{s p}$

$\overline{T_{\text {heater }}}$

$\overline{T_{\text {evap }}}$

$\overline{T_{\text {cond }}}$

$T_{\text {cool }}$

$\mathrm{R}_{\mathrm{OHP}}$

RSYS

$r_{x x}$

$\mathrm{Q}$

$u_{c}$

$u_{i}$

$v_{i}$

$v_{e f f}$

$\mathrm{V}$

$x_{i}$

\author{
Bond Number \\ Direct Current \\ Oscillating heat pipe \\ Power Spectrum Density (Energy/frequency) \\ Phase Change Material \\ Volume fraction, ((Volume of charged working fluid)/(Total volume of OHP) $) \times 100 \%$
}

Real part

Imaginary part

Coverage factor

Critical diameter $(\mathrm{m})$

Inner diameter $(\mathrm{m})$

Outer diameter $(\mathrm{m})$

Gravitational acceleration $\left(\mathrm{m} / \mathrm{s}^{2}\right)$

Electric current (A)

Sampling number

Turn of number of OHP

Number of input data points

Average temperature of heater $\left({ }^{\circ} \mathrm{C}\right)$

Average temperature of evaporator section of $\mathrm{OHP}\left({ }^{\circ} \mathrm{C}\right)$

Average temperature of condition section of $\mathrm{OHP}\left({ }^{\circ} \mathrm{C}\right)$

Temperature of coolant $\left({ }^{\circ} \mathrm{C}\right)$

Thermal resistance of $\mathrm{OHP}\left(\mathrm{W} /{ }^{\circ} \mathrm{C}\right)$

Thermal resistance of system $\left(\mathrm{W} /{ }^{\circ} \mathrm{C}\right)$

Auto-correlation function of the input signal

Heating of heater $(\mathrm{W})$

Combined uncertainty

Standard uncertainty

Degree of freedom

Effective degree of freedom

Voltage (W)

Parameters of the thermal resistance 


\section{Greek Letters}

$\begin{array}{ll}\alpha & \text { Angle }\left(^{\circ}\right) \\ \beta & \text { Angle }\left(^{\circ}\right) \\ \sigma & \text { Surface Tension }(\mathrm{N} / \mathrm{m}) \\ \rho_{l} & \text { Density of liquid }\left(\mathrm{kg} / \mathrm{m}^{3}\right) \\ \rho_{v} & \text { Density of vapor }\left(\mathrm{kg} / \mathrm{m}^{3}\right) \\ \sigma_{i} & \text { Standard error } \\ \Delta t & \text { Sampling interval }(\mathrm{s}) \\ \Delta T & \text { Temperature difference }\left({ }^{\circ} \mathrm{C}\right)\end{array}$

\section{References}

1. International Energy Agency. Global EV Outlook 2018; International Energy Agency: Paris, France, 2018; pp. 58-59.

2. Thomas, B.R.; David, L. Linden's Handbook of Batteries, 4rd ed.; McGraw-Hill: New York, NY, USA, 2011; pp. 331-417.

3. Li, H.L.; Su, J.R. Cycle-life prediction model studies of lithium-ion batteries. Chin. J. Power Sources 2008, 32, 242-246.

4. Forgez, C.; Do, D.V.; Friedrich, G. Thermal modeling of a cylindrical LiFePO4/graphite lithium-ion battery. J. Power Sources 2010, 195, 2961-2968. [CrossRef]

5. Jeon, D.H.; Baek, S.M. Thermal modeling of cylindrical lithium ion battery during discharge cycle. Energy Convers. Manag. 2011, 52, 2973-2981. [CrossRef]

6. Viswanathan, V.V.; Choi, D.; Wang, D. Effect of entropy change of lithium intercalation in cathodes and anodes on Li-ion battery thermal management. J. Power Sources 2010, 195, 3720-3729. [CrossRef]

7. Xia, G.D.; Cao, L.; Bi, G.L. A review on battery thermal management in electric vehicle application. J. Power Sources 2017, 367, 90-105. [CrossRef]

8. Heubner, C.; Schneider, M.; LaMmel, C. Local Heat Generation in a Single Stack Lithium Ion Battery Cell. Electrochim. Acta 2015, 186, 404-412. [CrossRef]

9. Liu, G.M.; Ouyang, M.; Lu, L.G. Analysis of the heat generation of lithium-ion battery during charging and discharging considering different influencing factors. J. Therm. Anal. Calorim. 2014, 116, 1001-1010. [CrossRef]

10. Bandhauer, T.M.; Garimella, S.; Fuller, T.F. Temperature-dependent electrochemical heat generation in a commercial lithium-ion battery. J. Power Sources 2014, 247, 618-628. [CrossRef]

11. Panchal, S.; Dincer, I.; Agelin-Chaab, M.; Fraser, R.; Fowler, M. Experimental and theoretical investigations of heat generation rates for a water cooled $\mathrm{LiFePO}_{4}$ battery. Int. J. Heat Mass Transf. 2016, 101, 1093-1102. [CrossRef]

12. Choi, Y.S.; Kang, D.M. Prediction of thermal behaviors of an air-cooled lithium-ion battery system for hybrid electric vehicles. J. Power Sources 2014, 270, 273-280. [CrossRef]

13. Yu, K.Y.; Yang, X.; Cheng, Y.Z. Thermal analysis and two-directional air flow thermal management for lithium-ion battery pack. J. Power Sources 2014, 270, 193-200. [CrossRef]

14. Ling, Z.Y.; Wang, F.X.; Fang, X.M. Hybrid thermal management system for lithium ion batteries combining phase change materials with forced-air cooling. Appl. Energy 2015, 148, 403-409. [CrossRef]

15. Bai, F.F.; Chen, M.B.; Song, W.J.; Feng, Z.P. Thermal management performances of PCM/water cooling-plate using for lithium-ion battery module based on non-uniform internal heat source. Appl. Therm. Eng. 2017, 126, 17-27. [CrossRef]

16. Tong, W.; Somasundaram, K.; Birgersson, E. Numerical investigation of water cooling for a lithium-ion bipolar battery pack. Int. J. Therm. Sci. 2015, 94, 259-269. [CrossRef]

17. Huo, Y.T.; Rao, Z.H.; Liu, X.J. Investigation of power battery thermal management by using mini-channel cold plate. Energy Convers. Manag. 2015, 89, 387-395. [CrossRef]

18. Panchal, S.; Haji, M.; Akhoundzadeh, K.; Raahemifar, M.; Fraser, R.; Fowler, M. Heat and mass transfer modeling and investigation of multiple LiFePO4/graphite batteries in a pack at low C-rates with water-cooling. Int. J. Heat Mass Transf. 2019, 135, 368-377. [CrossRef] 
19. Liu, F.F.; Lan, F.C.; Chen, J.Q. Dynamic thermal characteristics of heat pipe via segmented thermal resistance model for electric vehicle battery cooling. J. Power Sources 2016, 321, 57-70. [CrossRef]

20. Wang, Q.; Jiang, B.; Xue, Q.F.; Sun, H.L.; Li, B.; Zou, H.M.; Yan, Y.Y. Experimental investigation on EV battery cooling and heating by heat pipes. Appl. Therm. Eng. 2015, 88, 54-60. [CrossRef]

21. Hong, S.H.; Wang, S.F.; Zhang, Z.G. Multiple orientations research on heat transfer performances of Ultra-Thin Loop Heat Pipes with different evaporator structures. Int. J. Heat Mass Transf. 2016, 98, 415-425. [CrossRef]

22. Rao, Z.H.; Huo, Y.T.; Liu, X.J. Experimental study of an OHP-cooled thermal management system for electric vehicle power battery. Exp. Therm. Fluid Sci. 2014, 57, 20-26. [CrossRef]

23. Wang, Q.C.; Rao, Z.H.; Huo, Y.T.; Wang, S.F. Thermal performance of phase change material/oscillating heat pipe-based battery thermal management system. Int. J. Therm. Sci. 2016, 102, 9-16. [CrossRef]

24. Qu, J.; Wang, C.; LI, X.J.; Wang, H. Heat transfer performance of flexible oscillating heat pipes for electric/hybrid-electric vehicle battery thermal management. Appl. Therm. Eng. 2018, 135, 1-9. [CrossRef]

25. Chi, R.G.; Chung, W.S.; Rhi, S.H. Thermal Characteristics of an Oscillating Heat Pipe Cooling System for Electric Vehicle Li-Ion Batteries. Energies 2018, 11, 655.

26. Zhao, R.; Zhang, S.; Liu, J. A review of thermal performance improving methods of lithium ion battery: Electrode modification and thermal management system. J. Power Sources 2015, 299, 557-577. [CrossRef]

27. Liu, H.Q.; Wei, Z.B.; He, W.D.; Zhao, J.Y. Thermal issues about Li-ion batteries and recent progress in battery thermal management systems: A review. Energy Convers. Manag. 2017, 150, 304-330. [CrossRef]

28. Chen, D.F.; Jiang, J.C.; Kim, G.H.; Yang, C.B.; Pesaran, A. Comparison of different cooling methods for lithium ion battery cells. Appl. Therm. Eng. 2016, 97, 846-854. [CrossRef]

29. Hu, Q.W.; Li, W.B.; Wang, Z.C. Review on Cooling Technique for Li-ion Battery Pack. Mar. Electr. Electron. Eng. 2016, 36, 53-58.

30. Riffat, S.; Mempouo, B.; Fang, W. Phase change material developments: A review. Int. J. Ambient. Energy 2013, 36, 102-115. [CrossRef]

31. Lin, Y.H.; Kang, S.W.; Chen, H.L. Effect of silver nano-fluid on pulsating heat pipe thermal performance. Appl. Therm. Eng. 2008, 28, 1312-1317. [CrossRef]

32. Cao, X.L.; Wang, W.; Chen, J.; Li, X.L.; Yu, S.X. Experimental Investigation on the Start-Up Characteristic of a Pulsating Heat Pipe. Fluid Mach. 2009, 37, 57-60.

33. Liang, J.W.; Chen, L.C.; He, G. Error Theory and Data Processing, 2nd ed.; China Metrology Publishing House: Beijing, China, 2001; pp. 67-71.

34. Origin Lab Corp. Help Manual. 2019. Available online: https://www.originlab.com/doc/Origin-Help/FFT1Algorithm (accessed on 20 January 2019). 